\title{
IMPLEMENTING BALANCED SCORECARD SUCCESSFULLY
}

Right strategic goals
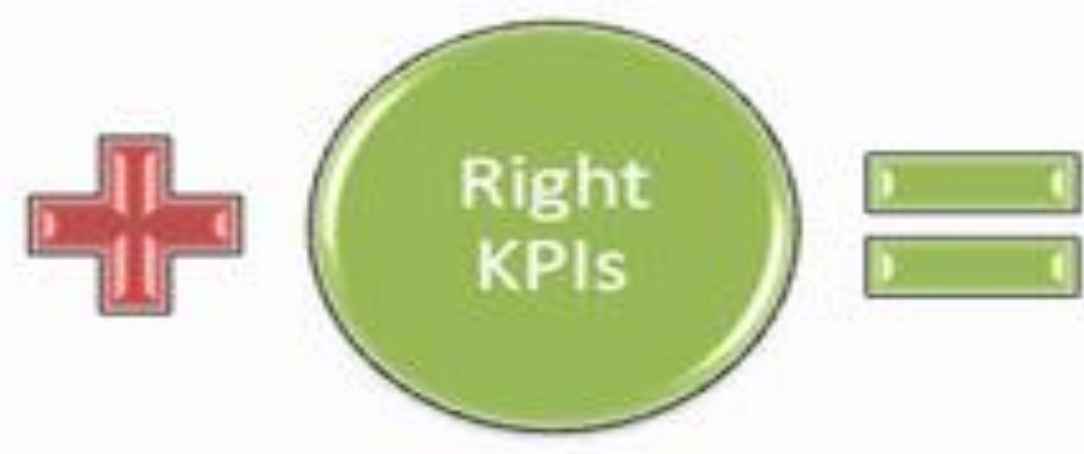

Successful BSC implementation

Disampaikan Pada Acara Morning Tea Discussion

Tanggal 22 Juli 2011

Universitas Kristen Maranatha Bandung 
- Menurut Drucker, efektivitas adalah dasar untuk bisa sukses, sedangkan efisiensi adalah kondisi minimum untuk bisa bertahan (survive) apabila sukses telah dicapai. Jadi, perusahaan harus mencapai dulu status terbaik yang bisa dilakukan terkait dengan kapasitas sumberdaya, baru kemudian melakukan langkah efisiensi. Dari sini dapat diungkapkan bahwa yang paling penting adalah penetapan the right things terlebih dahulu, yaitu visi atau tujuan perusahaan. Bila visi ini tidak ditentukan atau tidak ditentukan secara tepat, maka langkah-langkah efisiensi yang dilakukan akan merupakan waste (kesia-siaan) yang besar. Langkahlangkah efisiensi hanya akan bermanfaat bila perusahaan sudah berada pada track yang benar. 
- Drucker (1993) juga mengatakan bahwa inovasi merupakan "changing the yield of resources," dan inovasi lebih berada dalam konteks demand (konsumen) dari pada supply (faktor input produksi). Artinya, inovasi ditujukan untuk meningkatkan nilai dan kepuasan konsumen dengan penggunaan sumber daya yang dimiliki. Pendefinisian inovasi ini membawa kepada kesimpulan bahwa inovasi itu lebih sebagai upaya peningkatan efektivitas dari pada peningkatan efisiensi dalam penggunaan sumber daya 


\section{Kim dan Renee telah memetakan}

\section{"sebuah jalur baru dan berani untuk memenangi masa depan.}

- "Ciptakan ruang pasar tanpa pesaing, dan biarkan kompetisi tak lagi relevan"

- Perusahaan harus paham dimana posisinya sekarang.

- Kita harus mampu mengidentifikasi posisi diri terlebih dulu.

- Kita harus tahu, di mana kita berdiri sekarang.

- Perusahaan harus mampu dan paham benar posisi dirinya ada di mana di dalam industri yang ditekuni. Dengan demikian, kita akan menyadari bahwa kita tidak sendirian di dalam industri yang kita tekuni. Kita punya banyak pesaing.

- Setelah itu, kreativitas dan imajinasilah yang bekerja. Bergerak dari posisi sekarang, "as is", menuju sesuatu yang diinginkan, "to be". Di sini, hanya ada dua poin utama yang harus kita perhatikan. 


\section{Kim dan Renee telah memetakan Enam langkah untuk menjadi pemimpin pasar}

- 1. Cara merekonstruksi batas-batas pasar,

2. Berfokus pada gambaran besar,

3. Melampaui tuntutan yang ada,

4. Merancang rangkaian strategi dengan benar,

5. Mengatasi rintangan-rintangan organisasional,

6. Mengintegrasikan ekskusi ke dalam strategi.

- Buatlah perbedaan yang bukan sekadar berbeda, tapi bisa mengeliminasi biaya sehingga menjadi lebih murah, dan tetap memberi nilai tambah 
BSC Role

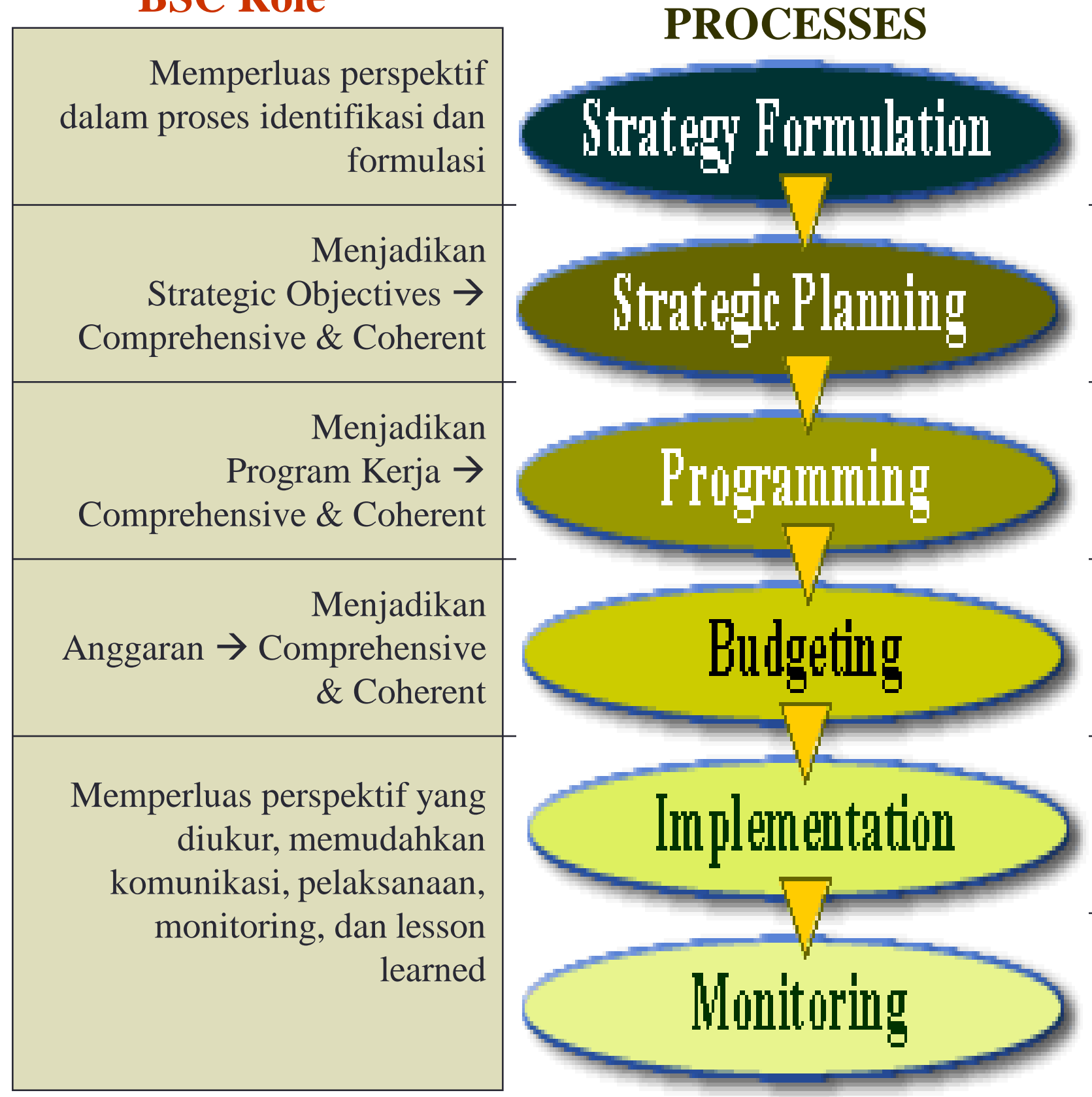

BSC Concept

\section{Output}

Mission, Vision, Core

Values, Core Beliefs, Goals, Strategy

Strategic Objectives,

Measures, Target, Strategic

Initiatives

Programs (Program Kerja -

Rencana Jangka Panjang)

Budget (Anggaran -

Rencana Jangka Pendek $\rightarrow$ 1 tahun)

Pelaksanaan Rencana:

Target tercapai atau tidak ..

Umpan Balik, Lesson

Learned 
BsC communicates to each unit, team, and individual should be able to articulate exactly how they contribute

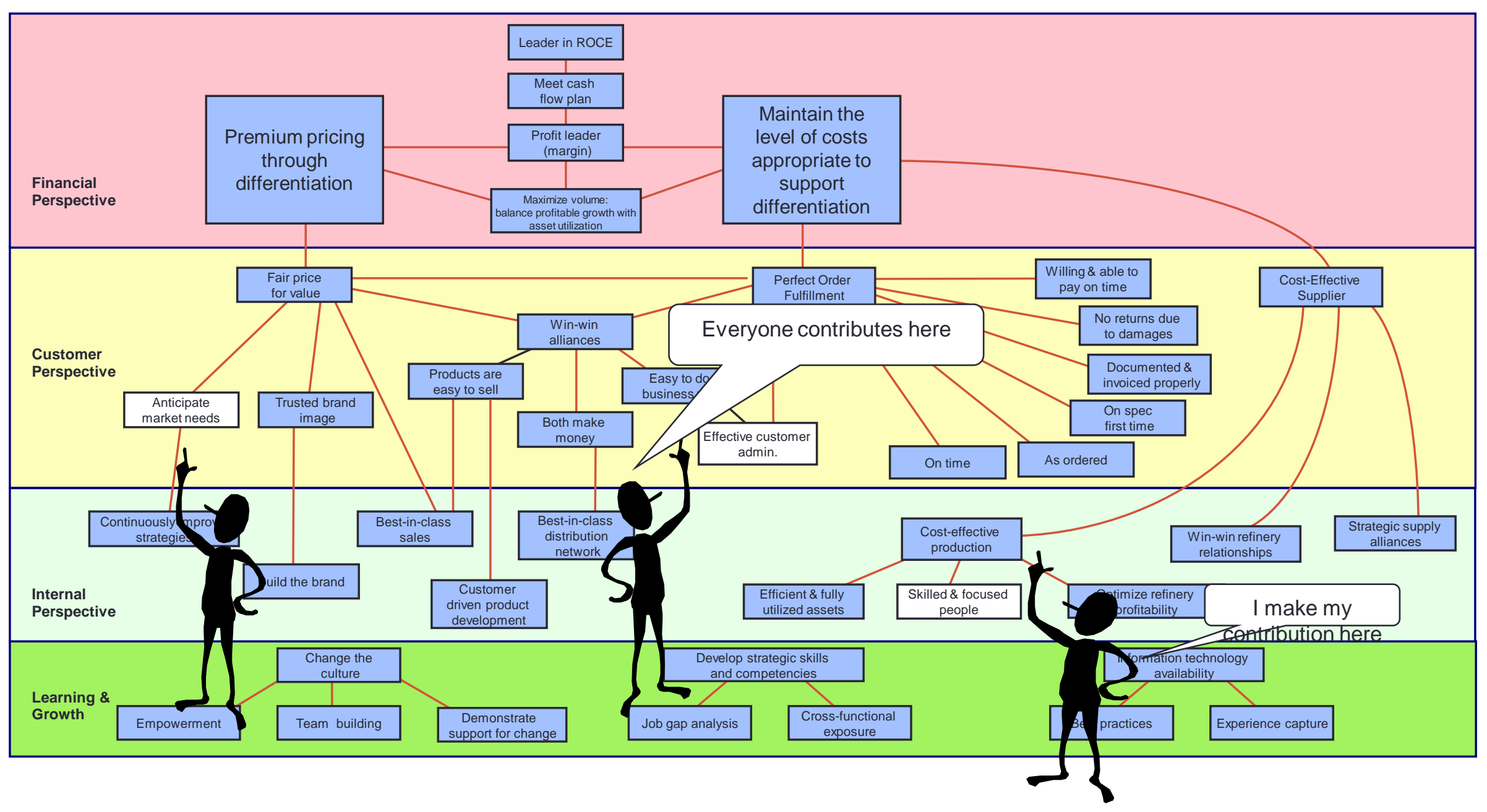


Research Oleh :

Kotter \& Heskett "Corporate Culture and Performance"

\section{Data Research :}

Dampak perusahaan yang memiliki budaya yang kuat :

- Revenue $4 x$ lebih tinggi,

- Kualitas tenaga kerja $7 x$ lebih baik,

- Nilai saham $12 x$ lebih tinggi

- Keuntungan bersih lebih dari $700 \%$

Collins Porras "Built to Last"
Dampak perusahaan yang memiliki misi visi yang jelas, terhadap kinerja keuangan :

- Market umum naik $15 x$ lebih tinggi

- Meningkat $16 x$ lebih tinggi terhadap perusahaan sejenis

Dampak perusahaan yang memiliki budaya yang lemah :

- Penurunan nilai aset sebesar $82 \%$ dalam jangka waktu 3 tahun

- Turn over karyawan hingga 50\%"
Jim Ware "Investment Leadership" 


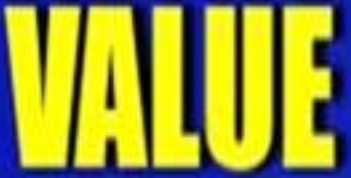

- Internalization

- Externalization

- Habits/ characters

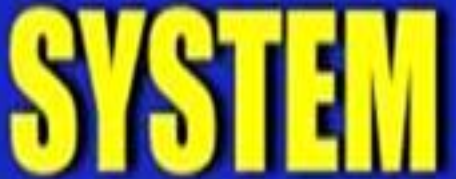

- Regulations

- HR Policies

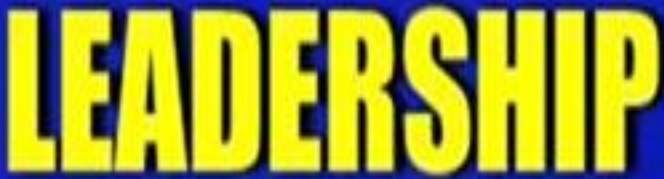

- Role model

- Change leaders

- Coach

The real role of the leader is to manage the values of the corporation.

-Tom Peters- 


\section{The Basis for Good \\ Strategic Decisions}

\section{Intuition + Analysis}

I

Effective Strategic Decisions 


\section{What Traits CEOs Have Now - And Will Need in the Year 2000}

Personal Behaviors

Conveys strong sense of vision

Links compensation to performance

Communicates frequently with employees

Emphasizes ethics

Plans for management succession

Communicates frequently with customers

Reassigns or terminates

Rewards loyalty

Makes all major decisions

Behaves conservatively
Now

$75 \%$

$66 \%$

$\mathbf{5 9 \%}$

$74 \%$

$56 \%$

$41 \%$

$34 \%$

$39 \%$

$39 \%$

$32 \%$
Year 2000

98\%

$91 \%$

89\%

$85 \%$

$85 \%$

$78 \%$

$71 \%$

$44 \%$

$21 \%$

$13 \%$ 


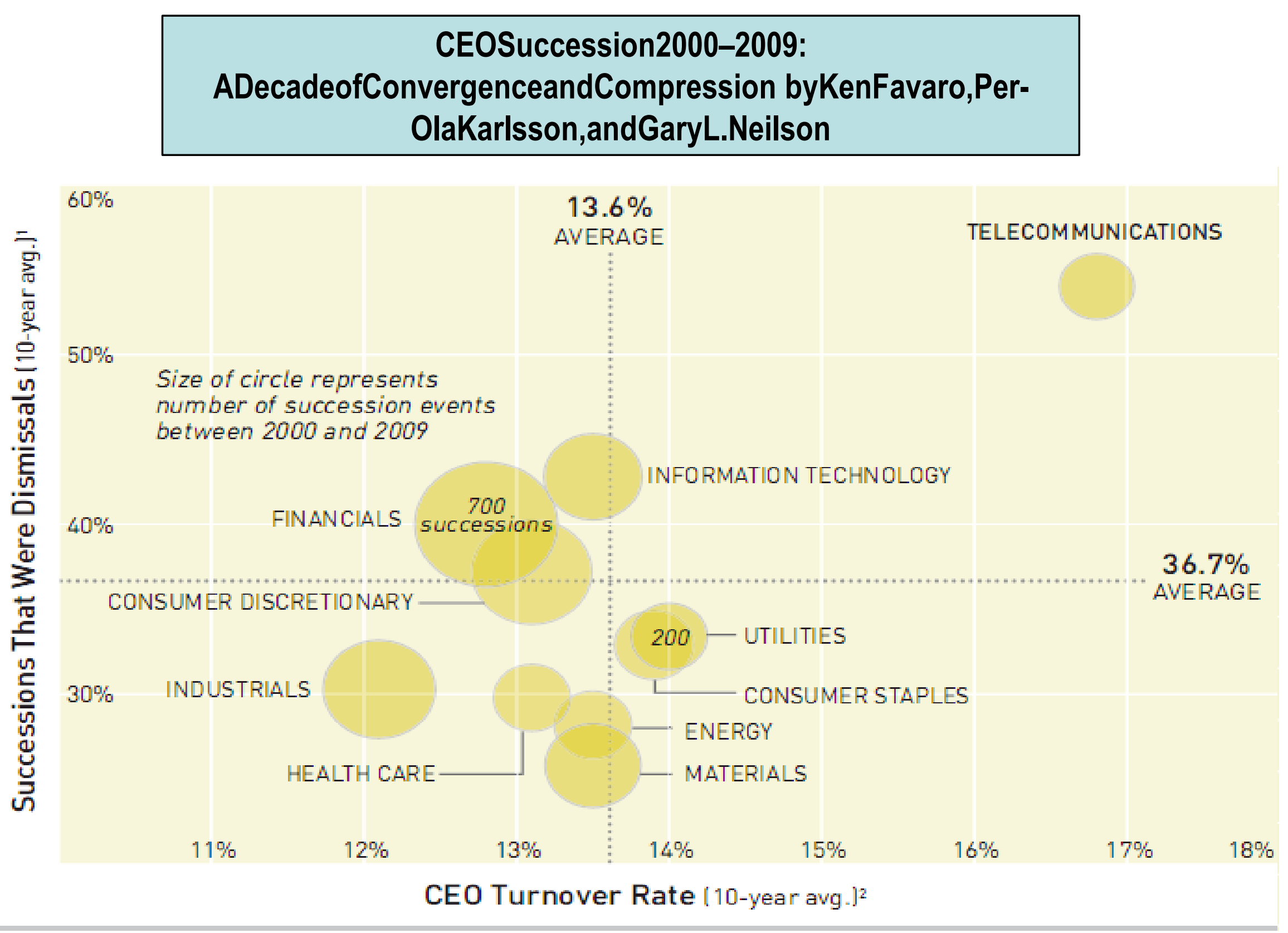




\section{Macam-macam keunggulan bersaing perusahaan bisa meliputi :}

- Superiority in Price, Keunggulan bersaing karena harga. Harga disini tidak selalu harus lebih murah, boleh lebih tinggi tetapi pelanggan harus merasakan nilai tambah yang lebih besar dibandingkan harganya.

- Superiority quality and disain, keunggulan bersaing karena kualitas dan disain yang lebih baik dibandingkan dengan pesaing.

- Superiority in Customer responsiviness, keunggulan bersaing karena perusahaan mampu merespon need and wants customer.

- Superiority in inovation, Keunggulan bersaing karena inovasi yang terus menerus dilakukan oleh perusahaan.

- KeungguTan bersaing yang berkesinambungan dicapai pada saat perusahaan menerapkan suatu pencipta nilai dan perusahaan pesaing tidak secara berkesinambungan menerapkannya, serta saat perusahaan lain tidak mampu meniru keunggulan strategi tersebut. 


\section{CEO C-SUITE STUDIES IBM Global CEOs}

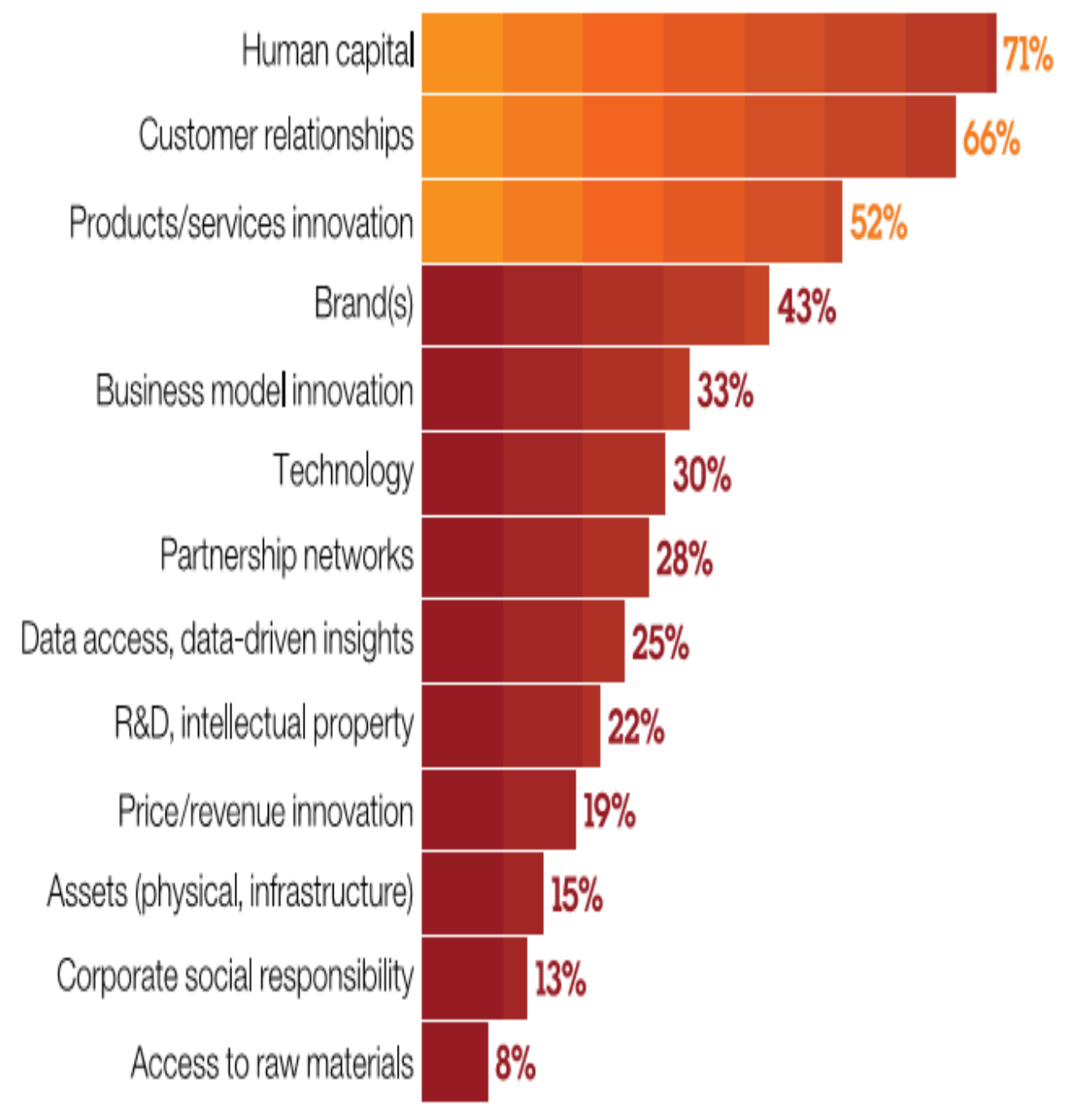

Figure 2

Prime sources More than half of all CEOS see human capital, customer relationships and innovation as key sources of sustained economic value. 


\section{CEO C-SUITE STUDIES}

IBM Global CEOs

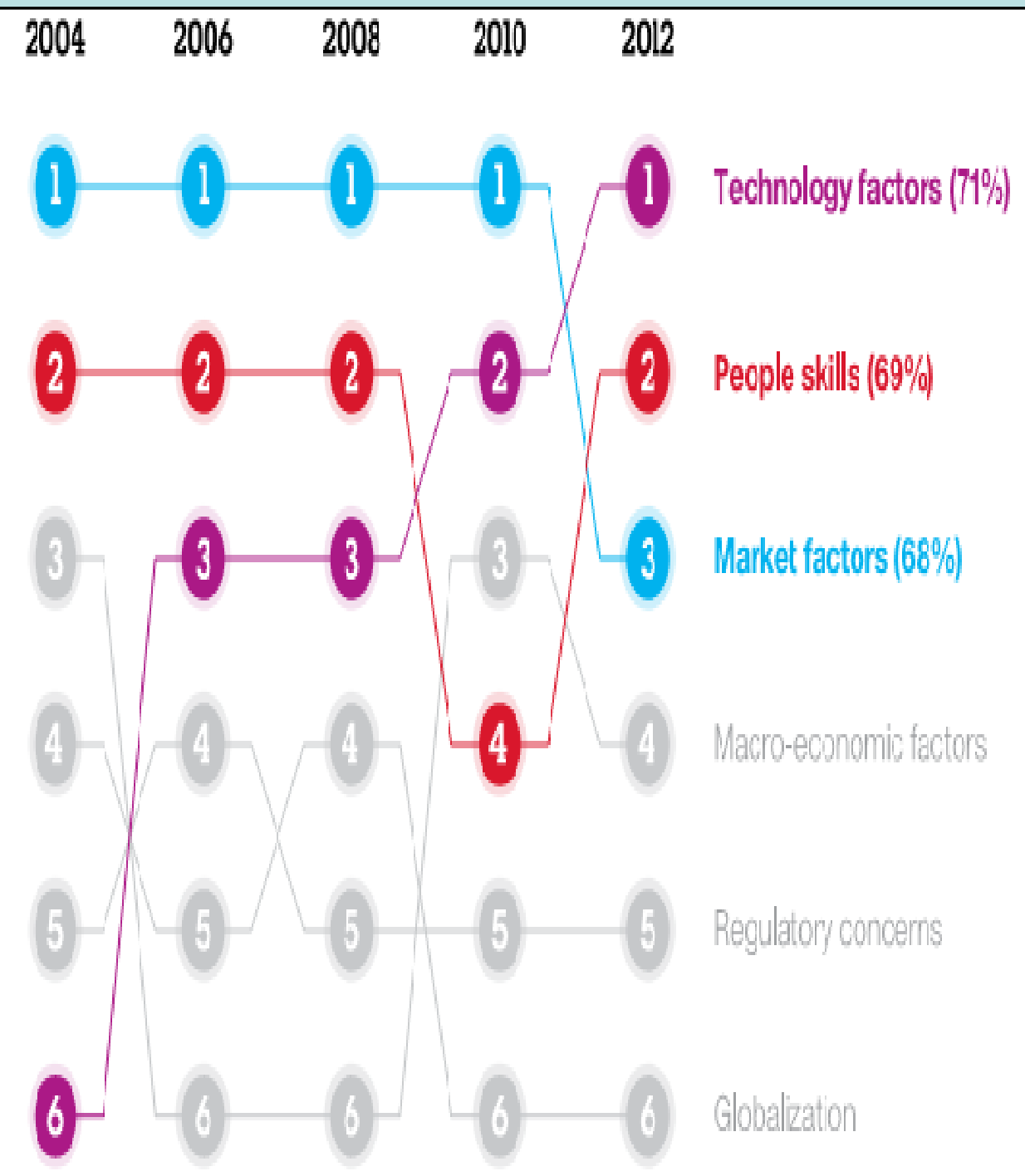

\section{Figure 1}

Technology pushes to tha top Ofall the external forces thatcould imoact thel' o rganizations over the next three iof fiveyears, CEOs now see tedhnology change as most critca. 


\section{Two-quotes}

- Saling ketergantungan pada sarana elektronik, menciptakan dunia ini dalam gambaran sebuah perkampungan dunia (Marshal H. McLuhan, The Medium is the Message, 1967).

- Globalisasi harus diterima sebagai kenyataan yang tidak bisa ditolak. Hanya ada satu standar kesuksesan perusahaan : pangsa pasar internasional (Jack Welch, CEO GE, 1994) 


\section{INPUT}

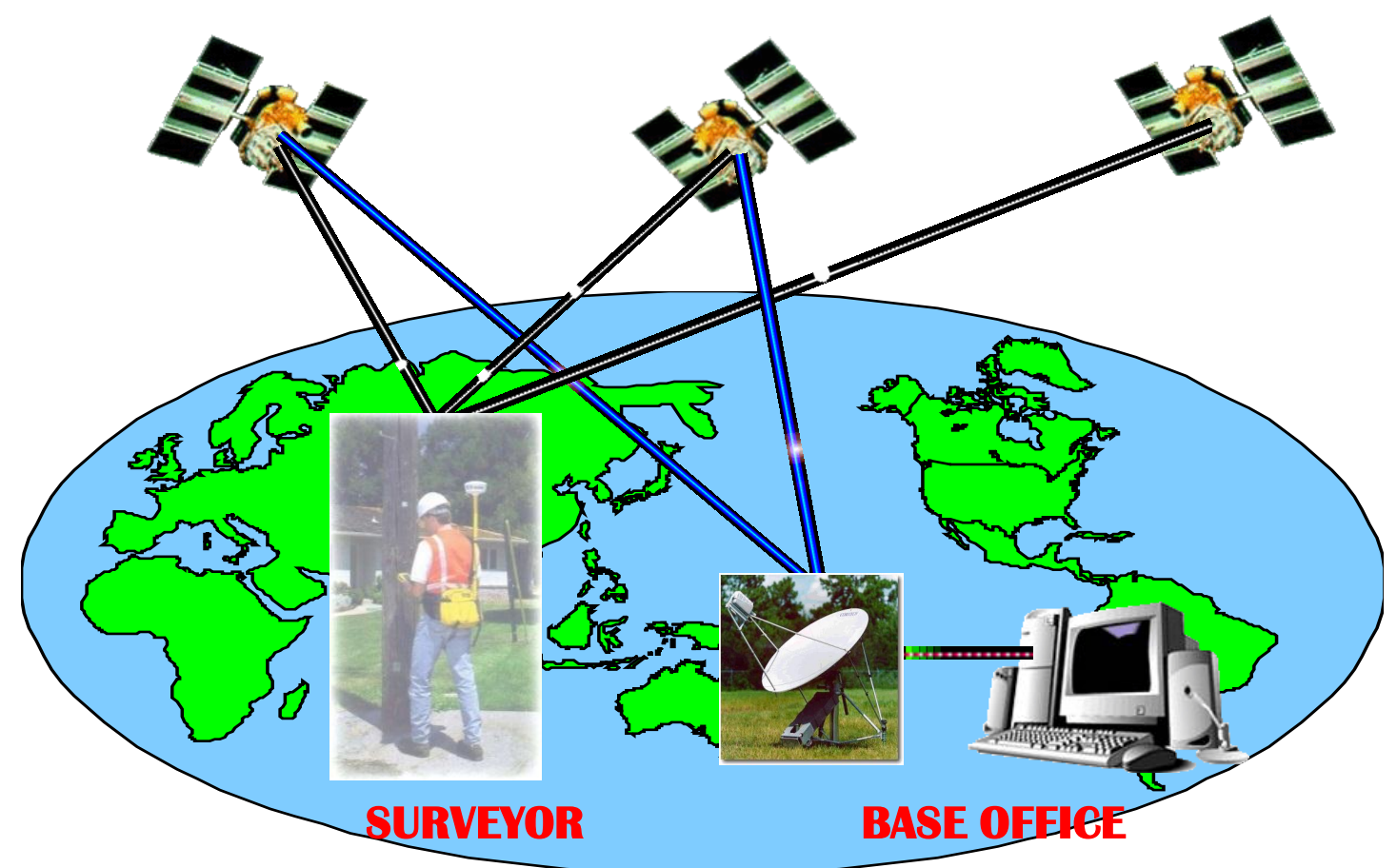

Hampir Semua Aspek usaha sudah terhubung melalui sistim informasi 


\section{Universitas Modern dan Bermutu}

berbasis Teknologi Informasi

\section{PERFORMANCE EXCELLENCE}

Perluasan Akses dan Peningkatan Kualitas Pendidikan dan Kemahasiswaan

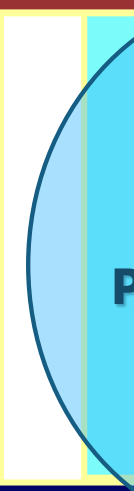

Peningkatan

Kualitas

Penelitian dan

Pengabdian

Masyarakat

\section{Penguatan Sistem Manajemen Mutu dan Informasi} (Berbasis pada Manajemen Kinerja- Balanced Scorecard)

\section{Bangunan Rencana Strategis UNNAR 2005-2015}




\section{ROADDAAP}

VISI

RENSTRA UNNAR 2005-2015 Modern dan Bermutu

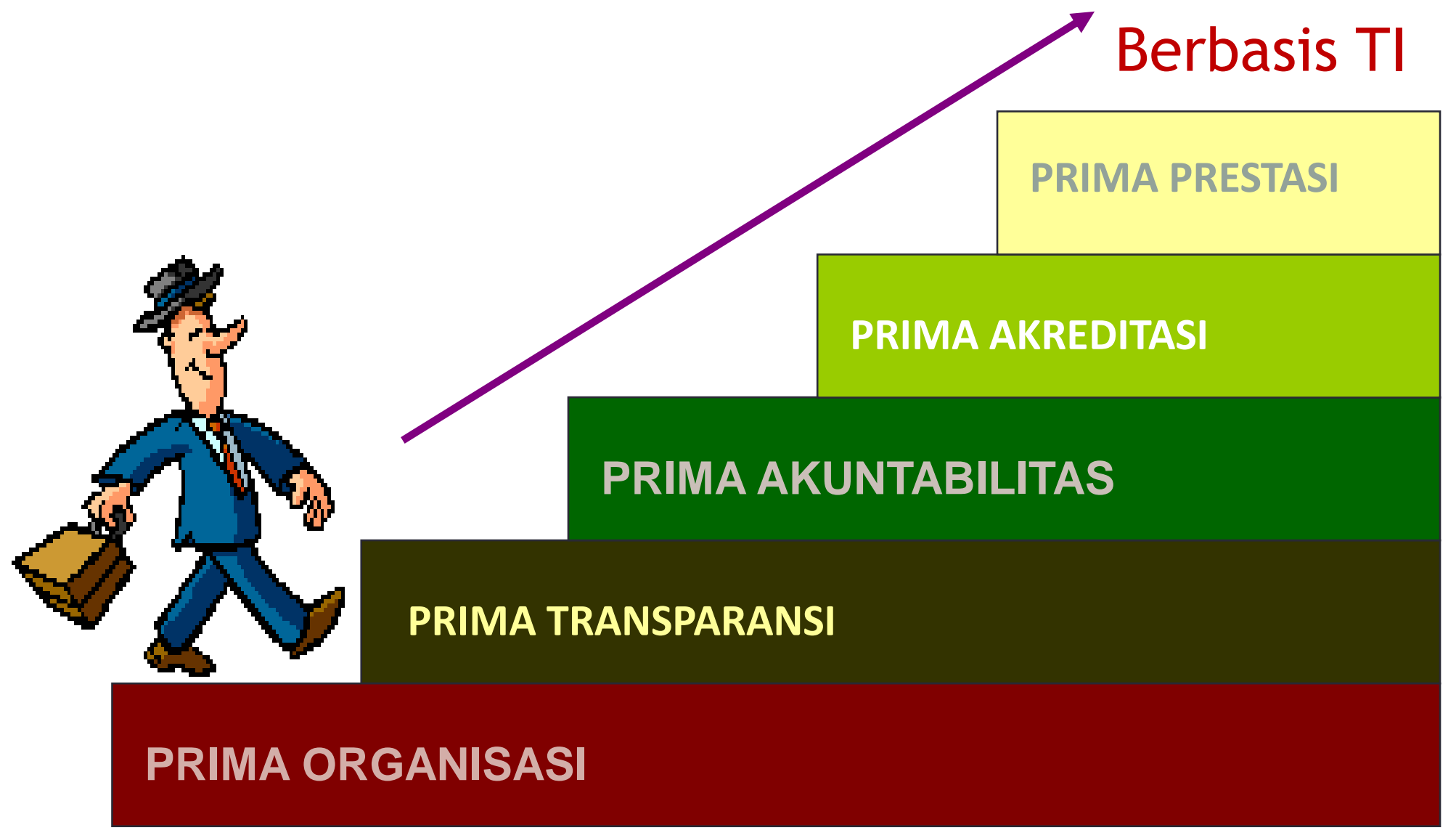
2015

2014

2011

2010

2009 


\section{Rencana Induk Pengembangan UNNAR}

TAHAPAN

\section{(1) 2005-2009}

(II) 2010-2012

(III) 2013-2015

\section{TARGET}

TRANSPARAN DANMENERAPKAN SISTEM INFORMASI

AKADEMIK

PENGUATANMANAIEMENMUTUDAN EFFIENSIMELALUI

SISTEM INFORMASITERINTEGRASI

MEN JADI PERGURUAN TINGGIYANGMODERN DAN BERMUTU

BERBASIS TEKNOLOGI INFORMASI 


\section{TAHAPAN PRIORITAS PENGEMBANGAN UNNAR}
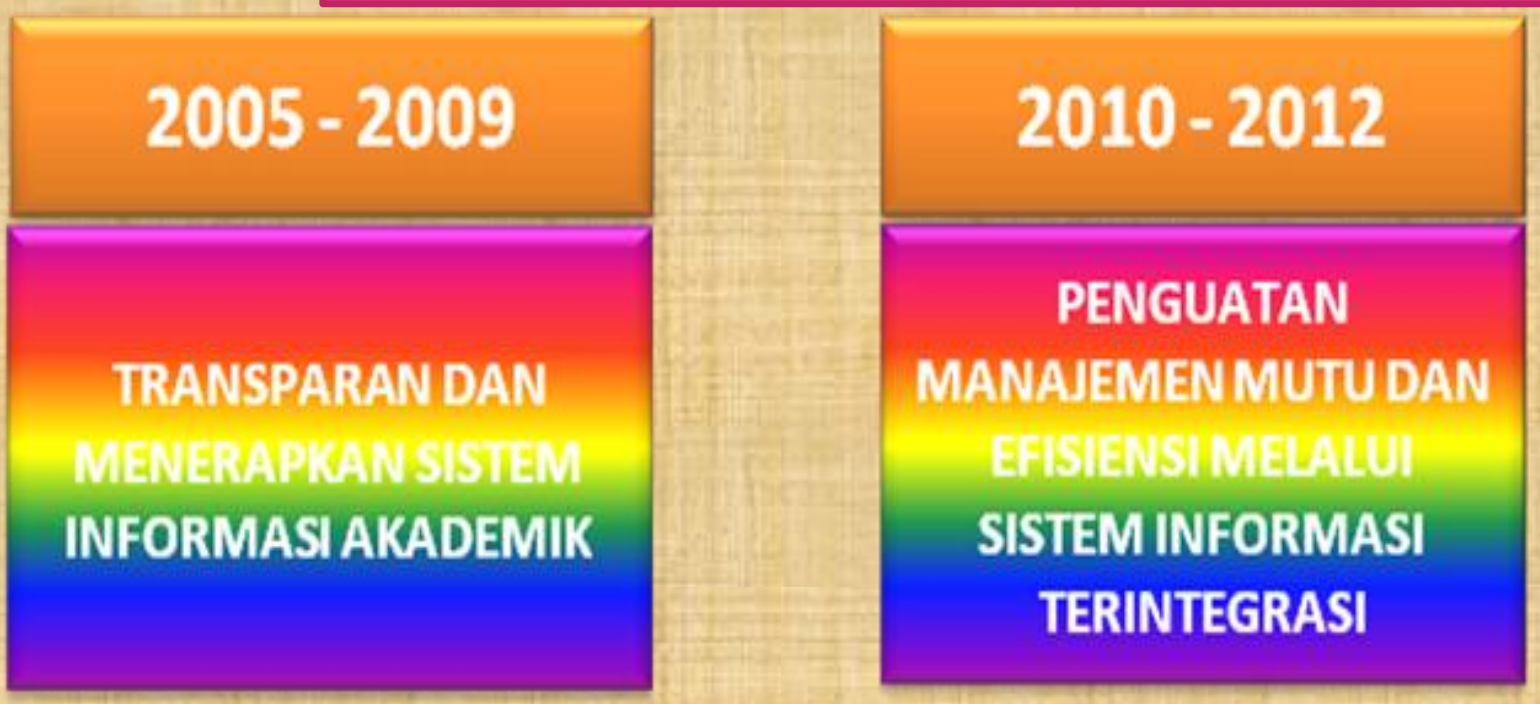

\section{$2013-2015$}

MEN JADI PERGURUAN

TINGCIYANGMODERM

DAN BERMUTU BERBASIS TEKNOLOGIINFORMASI

SUMBER DAYA INTERNAL : PERBAIKAN YANG BERKELANJUTAN OLEH UNIVERSITAS DALAM BENTUK RIP DAN SASARAN MUTUTAHUNAN

SUMBER DAYA EKSTERNAL : UNTUK MEMPERCEPAT PENCAPAIAN TARGET

SUMBER DAYA EKSTERNAL:

PROGRAM HIBAH KOMPETISI (DIKTI) 


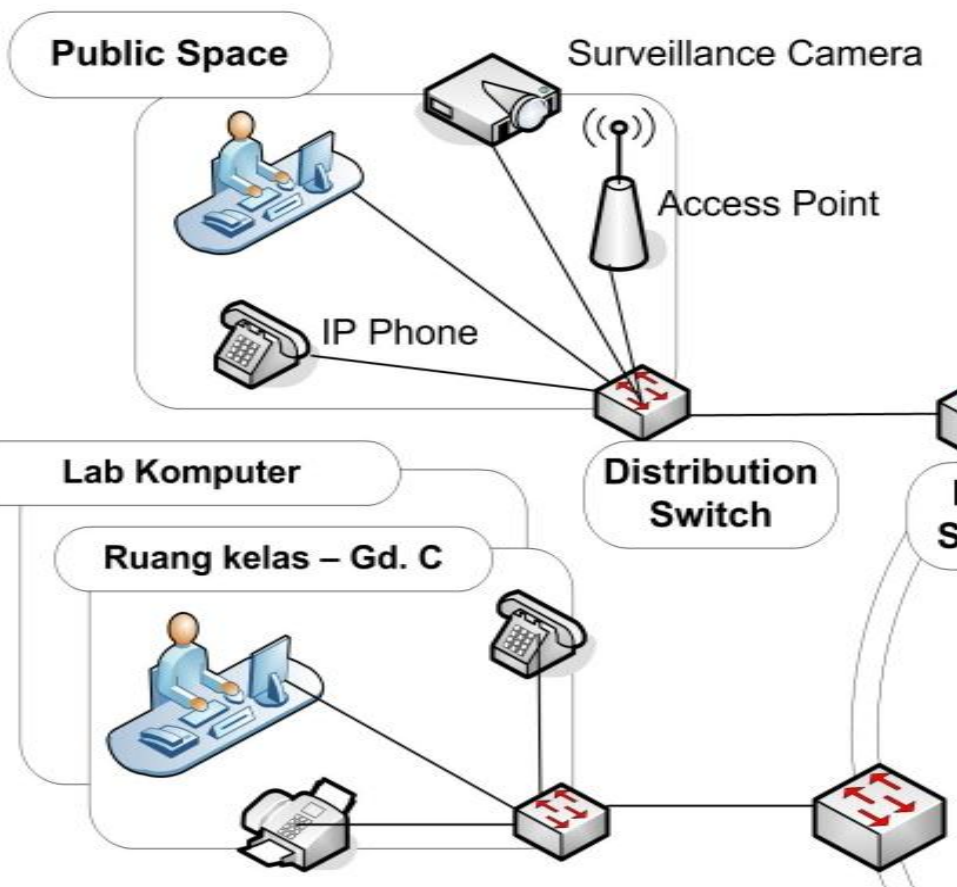

\section{Ruang Sidang}

UMKM Center

\section{Ruang kelas - Gd. B}

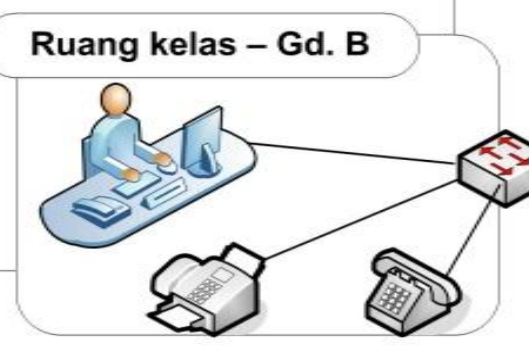

FO

Dual Ring

Topology

Edge
Switch
Internet

Cloud

INHERENT

Network
Ruang Serba Guna - Gd, A
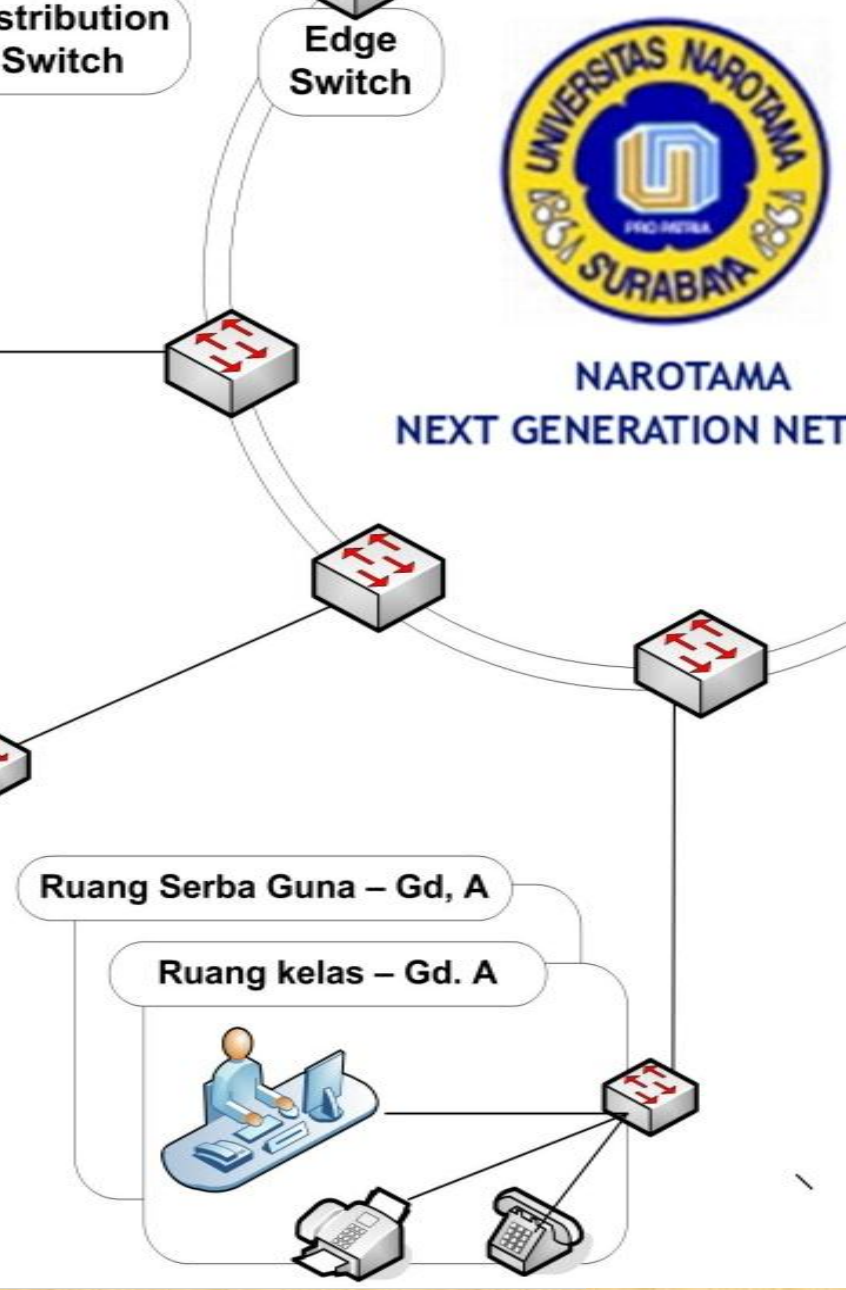

NAROTAMA NEXT GENERATION NETWORK

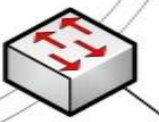
Network Operation Center

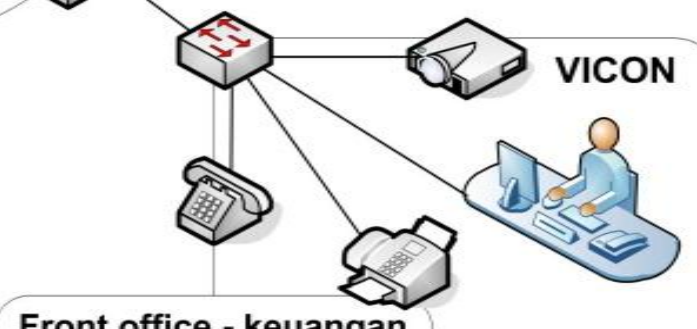

Front office - keuangan

\section{BAAK - Marketing}

LAB Komputer - LPPM

Ruang Rektor/Dekan/Dosen 


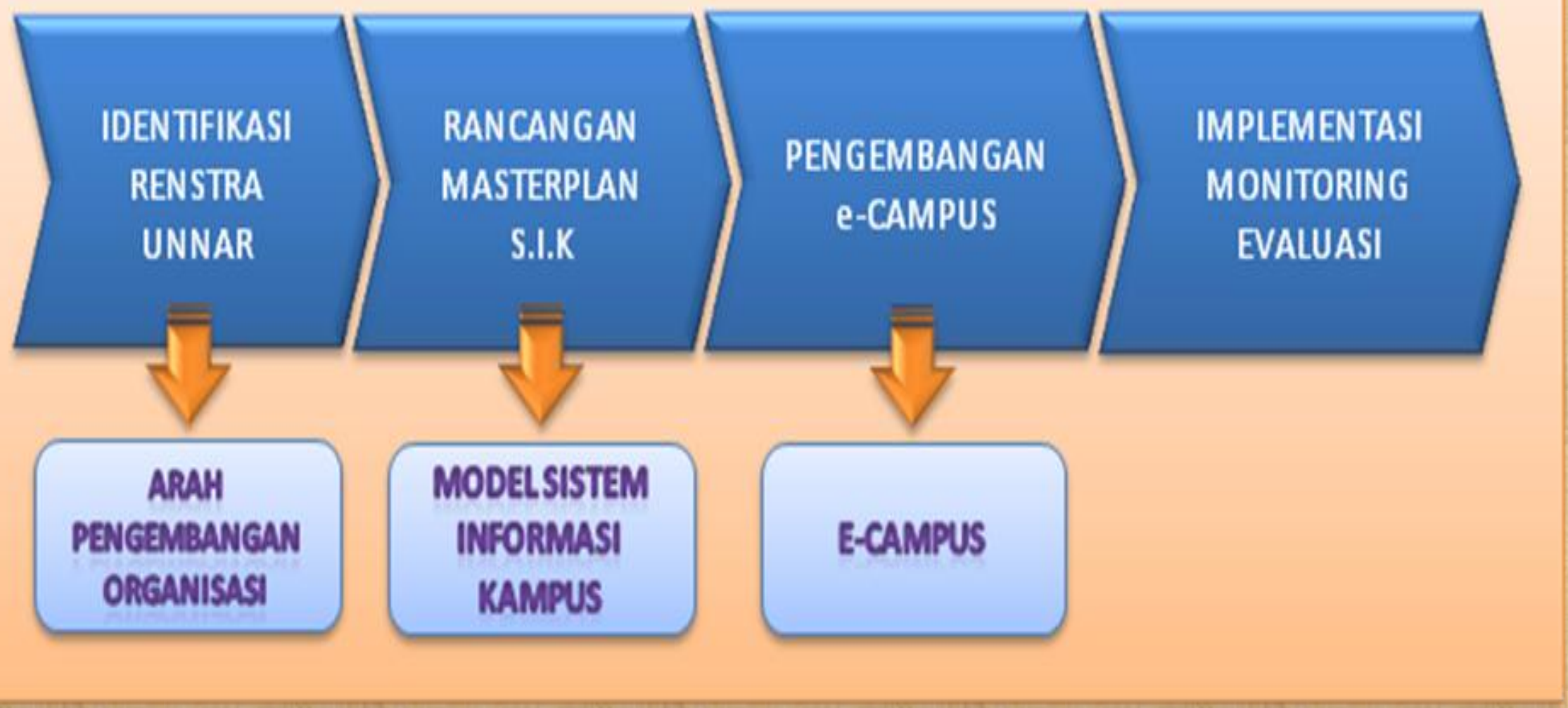

Model Pengembangan Sistem Informasi Kampus UNNAR 


\section{Balancen scorecard}

Period: 01 SEPTEMBER 2007 S/D 31 AGUSTUS 2008

Overall Performance

\section{FINANCIAL PERSPECTIVE}

MENU

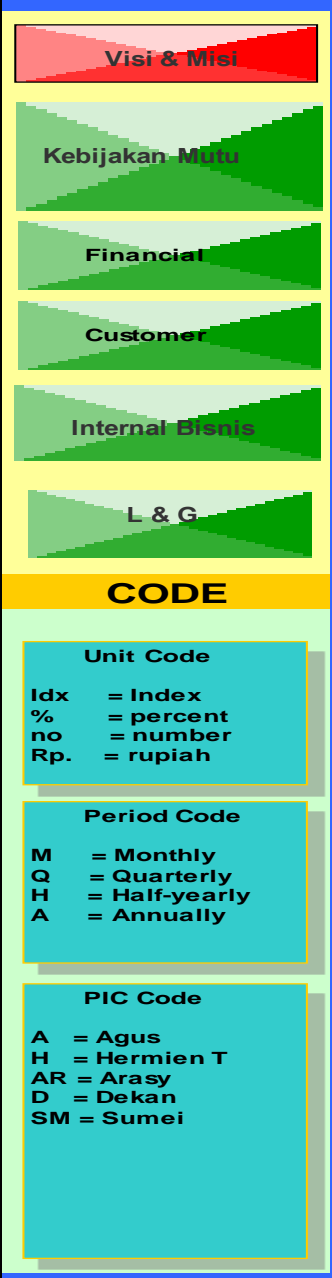

\section{INFO}

(c) Copyright, 2007 Universitas Narotama

(www.Rektor,Ac.Id)

Last update

3-Oct-12
5:02:39 PM

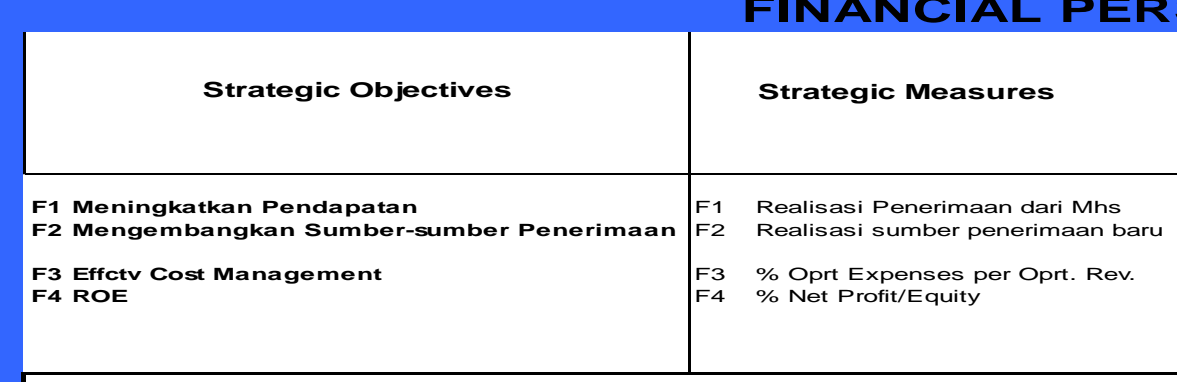

\begin{tabular}{|c|c|c|c|c|}
\hline 㗊 & $\begin{array}{l}\text { 罯. } \\
\end{array}$ & 믐 & $\begin{array}{l}\text { 品 } \\
\text { 总 } \\
\text { 㤐 }\end{array}$ & $\begin{array}{l}\text { 品 } \\
\text { 号 } \\
\text { 空 }\end{array}$ \\
\hline $\begin{array}{l}\text { Jt Rp. } \\
\text { Jt Rp. }\end{array}$ & $\begin{array}{l}Y \\
Y\end{array}$ & $\begin{array}{l}\text { A } \\
\text { A }\end{array}$ & $\begin{array}{r}5,748 \\
223\end{array}$ & $\begin{array}{r}4,828 \\
568\end{array}$ \\
\hline$\%$ & $Y$ & A & $56.57 \%$ & $79.25 \%$ \\
\hline$\%$ & Y & A & $3.13 \%$ & $0.51 \%$ \\
\hline
\end{tabular}

\section{CUSTOMER PERSPECTIVE}

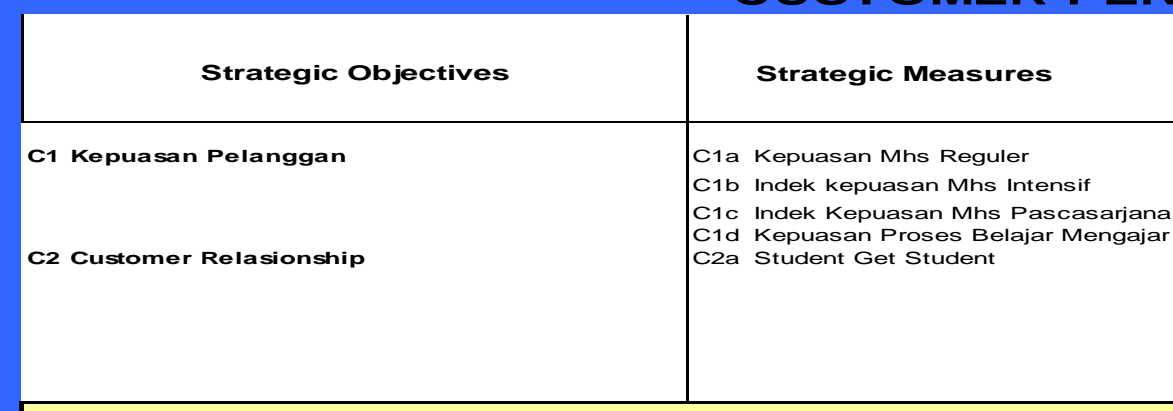

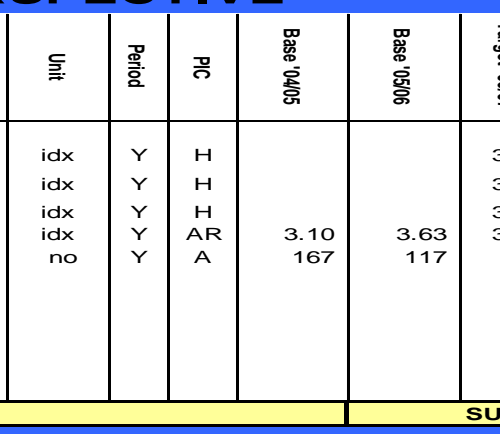

SUB-TOTAL
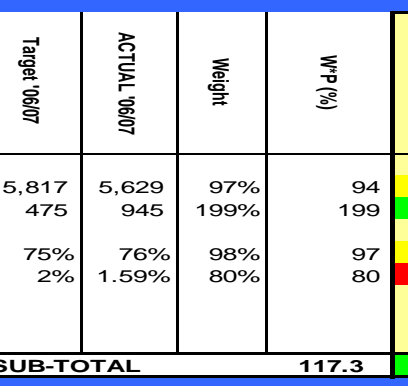

甾

\section{INTERNAL BUSINESS PROCESS}

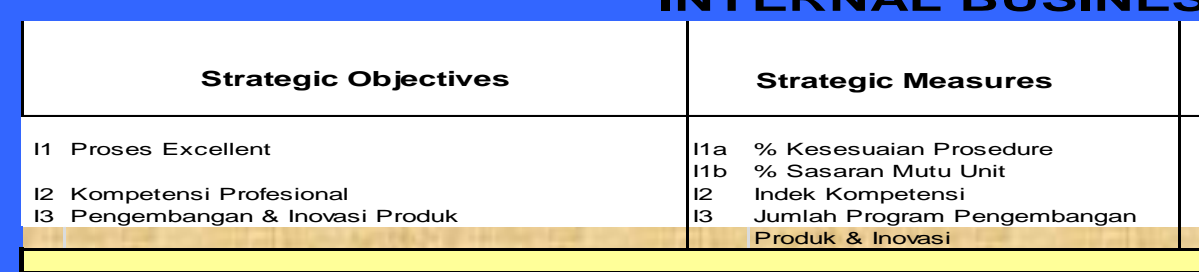

\begin{tabular}{|c|c|c|}
\hline 들 & $\begin{array}{l}\text { 兽. } \\
\text {. }\end{array}$ & 믕 \\
\hline$\%$ & $Y$ & $\mathrm{H}$ \\
\hline$\%$ & $Y$ & $\mathrm{H}$ \\
\hline idx & $\begin{array}{l}Y \\
Y\end{array}$ & A \\
\hline
\end{tabular}

\section{LEARNING AND GROWTH}

Strategic Objectives

Strategic Measures

\begin{tabular}{|c|c|c|c|}
\hline 谷 & $\begin{array}{l}\text { D. } \\
\text { 咅. }\end{array}$ & 끙 & 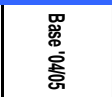 \\
\hline No & $Y$ & SM & 8.00 \\
\hline Id $x$ & $Y$ & SM & N/A \\
\hline$\%$ & $y$ & SM & N/A \\
\hline
\end{tabular}

SUB-TOTAL

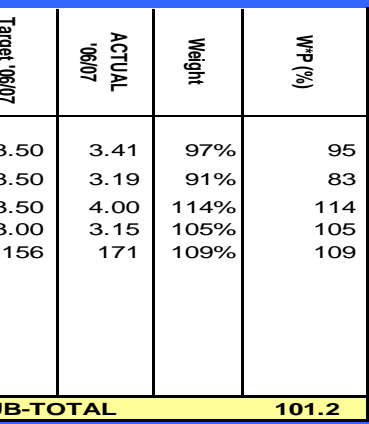

101.2

\begin{tabular}{|c|c|c|c|c|}
\hline $\begin{array}{l}\text { 怘 } \\
\text { 怘 } \\
\text { 今心 } \\
\text { 今. }\end{array}$ & 要离 & 兽总 & 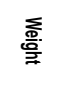 & $\frac{\gtrless}{\frac{3}{0}}$ \\
\hline 100 & 100 & 100 & $100 \%$ & 100 \\
\hline 100 & 100 & 190 & $190 \%$ & 100 \\
\hline N/A & 4 & 3.82 & $95 \%$ & 91 \\
\hline 19 & 10 & 17 & $170 \%$ & 100 \\
\hline
\end{tabular}

蔂

L1a Total Pelatihan Pengembangan SD \& Creativity

L2a Employee Performance idx

L2b Tingkat Absensi Alpa

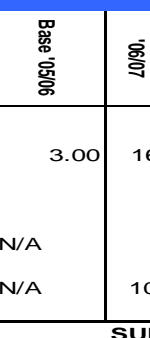

\begin{tabular}{|c|c|c|}
\hline 票営 & 容总 & 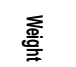 \\
\hline 16.00 & 17.00 & $106 \%$ \\
\hline 3.5 & 3.26 & $93 \%$ \\
\hline $100 \%$ & $97 \%$ & $97 \%$ \\
\hline
\end{tabular}

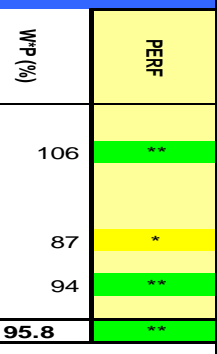




\section{Periode}

Laporan Chart Hasil Skor Final KPI Unit

Key Performance Indicator

: KPI Periode Genap 2012

Kategori Kinerja

: KPI REKTORAT

\begin{tabular}{|l|r|r|r|r|r|}
\hline \multicolumn{1}{|c|}{ Kategori Kinerja } & Skor Rata-rata & Bobot & Skor Terbobot & Skor Maksimal & Normalisasi \\
\hline KEPUASAN PELANGGAN & 3.86 & $30 \%$ & 1.16 & 1.2 & $96.67 \%$ \\
\hline PENDIDIKAN DAN PENGAJARAN & 4 & $30 \%$ & 1.2 & 1.2 & $100 \%$ \\
\hline PENGELOLAAN & 3.33 & $40 \%$ & 1.33 & 1.6 & $83.13 \%$ \\
\hline Jumlah & 11.19 & $100 \%$ & 3.69 & 4 & $93.27 \%$ \\
\hline
\end{tabular}

A (Sangat Baik) $\square$ B (Baik) C (Cukup) $\square D$ (Kurang)

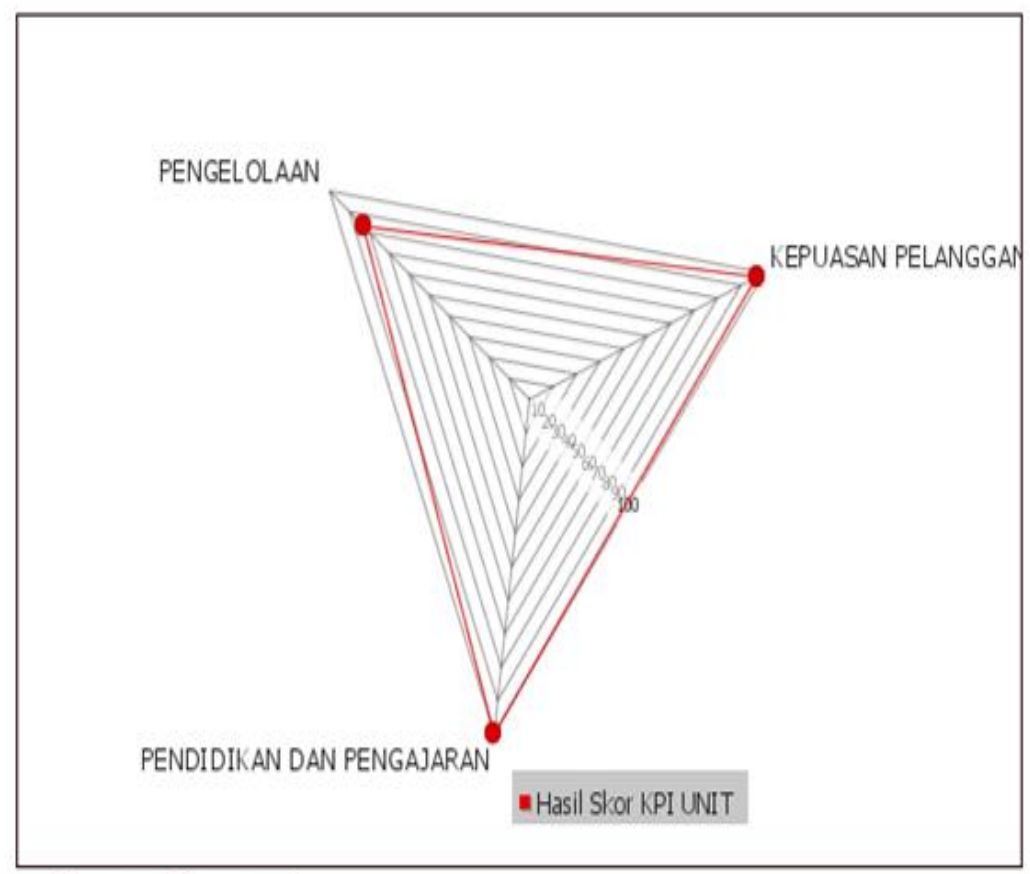




\section{Nama Perguruan Tinggi : : Universitas Narotama \\ Nama Fakultas : Fakultas Ekonomi \\ Nama Program Studi : Ekonomi Akuntansi}

\begin{tabular}{|l|l|r|r|r|}
\hline No. & \multicolumn{1}{|c|}{ Kriteria } & \multicolumn{1}{|c|}{$\begin{array}{c}\text { Skor } \\
\text { Akhir }\end{array}$} & \multicolumn{1}{|c|}{$\begin{array}{c}\text { Maksimum } \\
\text { Skor }\end{array}$} & Normalisasi \\
\hline 1 & STANDAR 1 Visi, Misi, Tujuan dan Sasaran, serta strategi Pencapaian & 6.24 & 12.48 & $50,00 \%$ \\
\hline 2 & $\begin{array}{l}\text { STANDAR 2 Tata Pamong, KEPEMIMPINAN, SISTEM Pengelolaan, DAN Penjaminan } \\
\text { Mutu }\end{array}$ & 16.63 & 24.96 & $66,63 \%$ \\
\hline 3 & STANDAR 3 KEMAHASISWAAN DAN LULUSAN & 41.02 & 62.4 & $65,74 \%$ \\
\hline 4 & STANDAR 4 SUMBER DAYA MANUSIA & 53.52 & 87.6 & $61,10 \%$ \\
\hline 5 & STANDAR 5 KURIKULUM, PEMBELAJARAN, DAN SUASANA AKADEMIK & 50.73 & 75.24 & $67,42 \%$ \\
\hline 6 & STANDAR 6 PEMBIAYAAN, PRASARANA, SARANA, DAN SISTEM INFORMASI & 39.63 & 62.48 & $63,43 \%$ \\
\hline 7 & $\begin{array}{l}\text { STANDAR 7. PENELITIAN, PELAYANAN/PENGABDIAN KEPADA MASYARAKAT, DAN } \\
\text { KERJASAMA }\end{array}$ & 60.09 & 75.12 & $79,99 \%$ \\
\hline Jumlah & 267,86 & 400,28 & $64,43 \%$ \\
\hline
\end{tabular}

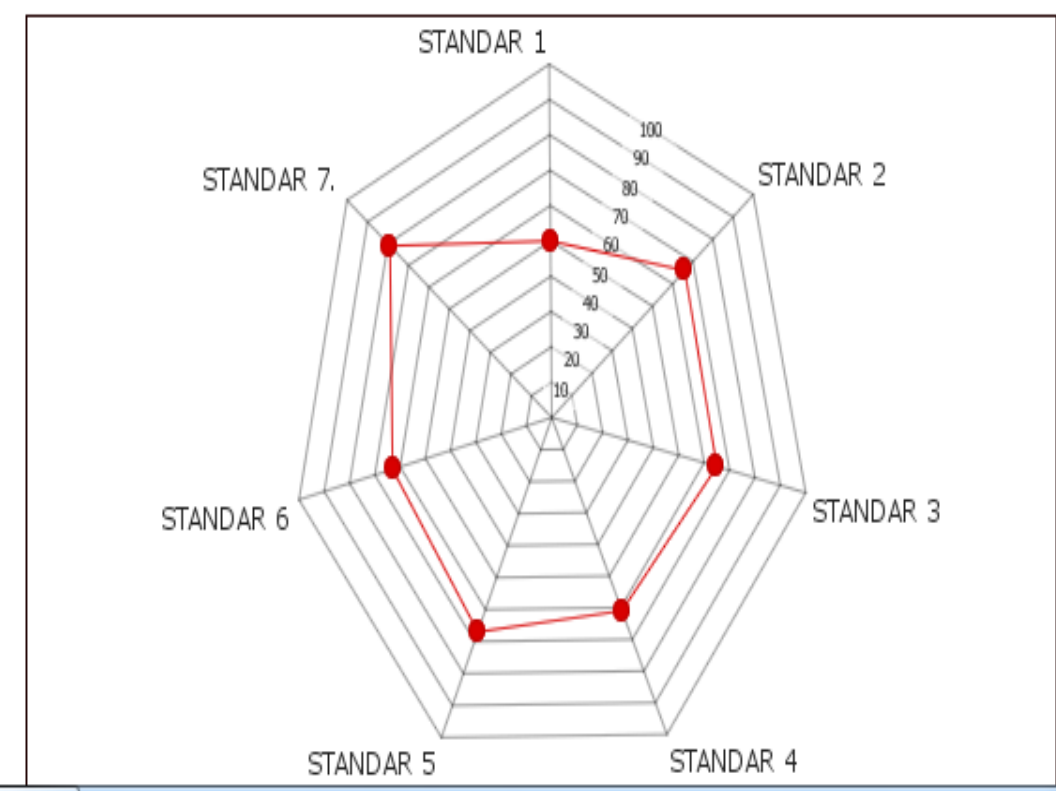




\section{Laporan Chart Hasil Skor Final KPI Pejabat}

Periode

: Periode KPI Tahun 2011 Ganjil

Key Performance Indicator

: KPI Warek I

\begin{tabular}{|l|r|r|r|r|r|}
\hline \multicolumn{1}{|c|}{ Kategori Kinerja } & Skor Rata-rata & Bobot & Skor Terbobot & Skor Maksimal & Normalisasi \\
\hline Kehadiran dikampus dan acara kampus & 4 & $5 \%$ & 0.2 & 0.2 & $\mathbf{1 0 0} \%$ \\
\hline Kinerja Akademik & 4 & $30 \%$ & 1.2 & 1.2 & $\mathbf{1 0 0} \%$ \\
\hline Pendidikan & 4 & $15 \%$ & 0.6 & $\mathbf{1 0 0} \%$ \\
\hline Penelitian & 4 & $15 \%$ & 0.6 & 0.6 & $\mathbf{1 0 0} \%$ \\
\hline Pengabdian Masyarakat & 4 & $10 \%$ & 0.4 & 0.4 & $\mathbf{1 0 0} \%$ \\
\hline Penilaian Manajemen & 4 & $5 \%$ & 0.2 & 0.2 & $\mathbf{1 0 0} \%$ \\
\hline Reputasi Lembaga & 3.67 & $10 \%$ & 0.37 & 0.4 & $\mathbf{9 2 . 5} \%$ \\
\hline Sistem Informasi & 4 & $10 \%$ & 0.4 & $\mathbf{1 0 0} \%$ \\
\hline Jumlah & 31.67 & $100 \%$ & 3.97 & 0.4 \\
\hline
\end{tabular}

A (Sangat Baik)

$B$ (Baik) $\square$ C (Cukup) $\square D$ (Kurang)

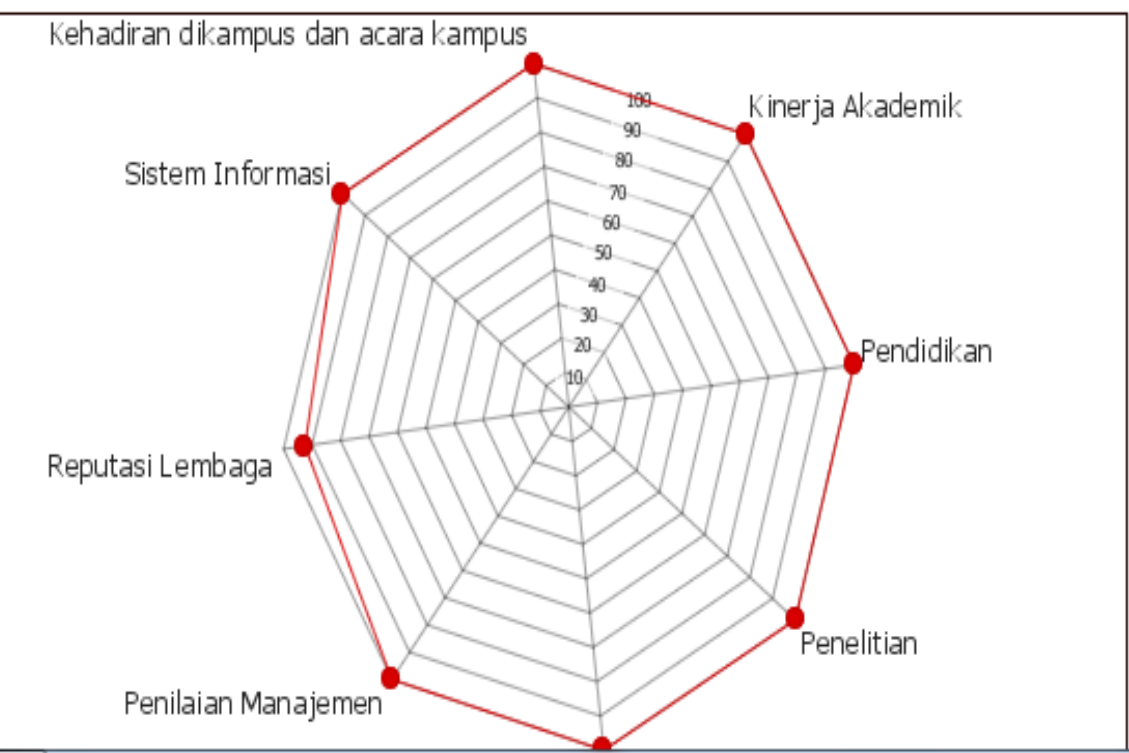


Tanggal : 03-10-2012

Nama Karyawan : 0005023 - NIKEN ARIEF RAHAYUANA, S.H.

Lihat

\section{Beban Kerja Karyawan}

\begin{tabular}{l|l|}
\hline \multicolumn{2}{l}{} \\
\hline NIP & 0005023 \\
\hline Nama & NIKEN ARIEF RAHAYUANA, S.H. \\
\hline Tempat, tanggal lahir & NGAWI, 30 April 1980 \\
\hline Alamat & Krian Indah Regency C1 No. 8 \\
\hline Email & Niken.Rahayuana@narotama.ac.id \\
\hline Unit Kerja & 1010 - Fakultas Ekonomi \\
\hline Jenis Pegawai & Karyawan \\
\hline Tipe Pegawai & Karyawan \\
\hline Status Keaktifan & Aktif \\
\hline
\end{tabular}

\begin{tabular}{|c|l|l|l|l|l|l|}
\hline Cek & \multicolumn{1}{|c|}{ Sasaran Mutu } & Kegiatan Yang Dilakukan & Jam Mulai & Jam Selesai & Valid? & Catatan MOD \\
\hline$\square$ & Pelayanan Mahasiswa & & & & \\
\hline$\square$ & Administrasi Akademik & & & & \\
\hline$\square$ & $\begin{array}{l}\text { Pengelolaan administrasi } \\
\text { keuangan }\end{array}$ & & & & \\
\hline$\square$ & Pelayanan Pejabat & & & \\
\hline$\square$ & Pengelolaan Kelas & & & \\
\hline$\square$ & Pengelolaan Administrasi SDM & & & \\
\hline$\square$ & PENDIDIKAN DAN PENGAJARAN & & & & \\
\hline$\square$ & $\begin{array}{l}\text { Pengelolaan Pembayaran } \\
\text { Mahasiswa }\end{array}$ & & & & \\
\hline$\square$ & Pelayanan Dosen & & & \\
\hline$\square$ & Arsip dan Laporan & & & \\
\hline
\end{tabular}

